\title{
Health Economic Evaluation of Different Decision Aids for the Individualised Treatment of Patients with Breast Cancer
}

\author{
Gesundheitsökonomische Betrachtung der unterschiedlichen Optionen \\ zur individualisierten Therapieentscheidung der Patientin mit einem Mammakarzinom
}

Authors

M. P. Lux ${ }^{1}$, T. Hildebrandt ${ }^{1}$, M. Bani ${ }^{1}$, C. R. Loehberg ${ }^{1}$, M. G. Schrauder ${ }^{1}$, C. Rauh ${ }^{1}$, S. M. Jud ${ }^{1}$, P. A. Fasching ${ }^{1}$, A. Hartmann ${ }^{2}$, M. W. Beckmann

Affiliations

${ }^{1}$ Frauenklinik, Universitätsklinikum Erlangen, Universitäts-Brustzentrum CCC ER-EMN, Erlangen
2 Institute of Pathology, Universitätsklinikum Erlangen, Universitäts-Brustzentrum CCC ER-EMN, Erlangen

\section{Key words}

breast cancer

cost-effectiveness

health economics

genetic tests

- QALY

\section{Schlüsselwörter}

- Mammakarzinom

- Kosteneffektivität

- Gesundheitsökonomie

- genetische Tests

- QALY

\section{Abstract \\ $\nabla$}

New molecular and genetic tests are becoming more and more important in research and clinical practice. Using these tests to offer individualised therapy to patients with breast cancer is particularly important in the context of health economics. The targeted use of therapies increases their effectiveness and reduces follow-up costs by preventing recurrence and metastatic disease. Avoiding over-treatment additionally reduces costs. Genetic tests are initially associated with higher costs but in the longer term they can reduce costs, as shown by health economic models and costeffectiveness analyses.

\section{Introduction}

In the German healthcare system we are currently seeing a rise in healthcare costs caused, among other things, by medical and technical advances, more diagnoses and therapies, demographic change, unemployment and a constant increase in the utilisation of "free" healthcare benefits. Healthcare costs are increasing exponentially and the costs of healthcare services in Germany are currently among the highest in the world. Health economic considerations have particularly focussed on breast cancer [19]. According to data from the German Federal Statistical Office, breast cancer is the commonest cause of death from malignant disease in women and the fourth most common cause of death for women in Germany [11]. According to recent data published by the Robert Koch Institute (for 2009/ 2010), 71660 women in Germany develop breast cancer in Germany every year [25]. Given that 17209 women with breast cancer die every year and that women with breast cancer are followed

\section{Zusammenfassung \\ $\nabla$}

Die individualisierte Therapie der Patientin mit einem Mammakarzinom durch neue Testverfahren, die derzeit sowohl die Forschung als auch den klinischen Alltag bestimmt, ist für die Gesundheitsökonomie besonders relevant, da sie durch den gezielteren Einsatz die Effektivität erhöht und somit Folgekosten durch die Vermeidung von Rezidiven und metastasierten Verläufen senkt. Zudem können durch die Vermeidung von Übertherapien Kosten reduziert werden. Genetische Tests sind zunächst mit erhöhten Kosten assoziiert. Auf die lange Sicht können jedoch Kosten eingespart werden, was durch gesundheitsökonomische Modelle mit Kosten-Effektivitäts-Analysen nachgewiesen werden kann.

\section{Einleitung}

$\nabla$

Im deutschen Gesundheitswesen beobachten wir derzeit eine Zunahme der Kosten für Gesundheitsausgaben, welche u.a. durch den medizinisch-technischen Fortschritt, die Erweiterung des diagnostischen und therapeutischen Angebots, die demografische Entwicklung, die Arbeitslosigkeit und die ständig wachsende Inanspruchnahme „kostenloser“ Gesundheitsleistungen bedingt ist. Diese Kosten steigen exponentiell an, und Deutschland liegt in Bezug auf die Kosten im Gesundheitswesen weltweit auf einem Spitzenplatz. Das Mammakarzinom steht im besonderen Fokus der gesundheitsökonomischen Betrachtungen [19]. Laut Angaben des Statistischen Bundesamts ist bei Frauen das Mammakarzinom die häufigste Todesursache unter den Malignomerkrankungen und stellt insgesamt die vierthäufigste bei Frauen dar [11]. Entsprechend den aktuellen Daten des Robert Koch-Instituts (Jahre 2009/2010) erkranken pro Jahr 71660 Frauen in Deutschland an einem Mammakarzinom [25]. Unter Berücksichtigung der Mortalität von 17209 Erkrankten pro Jahr und der 
up for 10 years after therapy, more than half a million women in Germany are currently being treated and/or followed up. In addition, an estimated 60000 women have metastatic disease. To put these figures into context, in 201032033000 adult women were living in Germany [6] - in other words, one in every 55 women is receiving oncologic care or follow-up for breast cancer. These figures make it obvious that the care of patients with breast cancer has an enormous health economic impact - both in an adjuvant and a palliative setting.

\section{Overview of the Health Economic Aspects of Individualised Therapy Options}

New molecular and genetic tests are becoming increasingly central in research and clinical practice. Using these tests to offer individualised treatment to patients with breast cancer is particularly important for health economics as the targeted use of therapy based on these tests can increase the effectiveness of treatment and reduce follow-up costs by preventing the recurrence and metastatic disease. Reducing over-treatment additionally saves financial resources, both directly and indirectly. Preventable direct costs include the costs of systemic therapies and supportive treatments. Preventable indirect costs include the cost of travel to clinics and medical practices, waiting times and reduced quality of life. Individualised therapy can help patients return to work earlier, with all the associated benefits this will have for the gross national product.

Drug therapies are associated with very high costs. Since 2004, the cost of drugs has been higher than the costs of medical treatment. One of the reasons for these higher costs is the prices of recently approved drugs, particularly in oncology. When it first came on the market tamoxifen cost \$ 100 per month in the USA. However, prices for drugs are now significantly higher; nab-paclitaxel, for example, costs more than $\$ 7500$ per month [10]. Moreover, as supportive therapies have improved and the management of side effects has got better, more patients now receive systemic therapies for longer periods of time. Currently, 15 billion USD are spent every year in the USA to treat breast cancer. The costs calculated for the year 2020 are expected to be just under 25 billion USD [10].

Studies generally consist of one cohort being given one form of therapy and the outcomes compared with those of another cohort which has either been treated using a different therapy or receive no therapy at all. The benefit of the therapy is then evaluated based on the increase in disease-free survival or overall survival. If the patient remains healthy, this could indicate that the treatment was effective and therefore the patient did not suffer a recurrence of disease. However, there is also the possibility that the patient would not, in any case, have suffered a recurrence and that her therapy therefore constituted a form of overtreatment ( Fig. 1). This clearly shows the importance of identifying those women in advance who will respond to a particular therapy or who are likely to suffer from specific side effects. Tests which support a decision for or against a specific drug therapy can be expected to play increasingly important roles in future. The molecular classification of breast carcinomas into subtypes such as luminal A, luminal B, HER2-positive or basal-like is becoming more central for decision-making on treatment strategies $[7,17,18,27]$. The existing data show that the classification of molecular subtypes is relevant for prognosis and that the decision on the choice of therapy can be made based on this classifi-
Durchführung einer 10-jährigen Nachsorge bis zum Abschluss der Erkrankung befinden sich derzeit über eine halbe Million Frauen in Deutschland in der Betreuung. Zudem sind geschätzt 60000 Frauen in der metastasierten Situation. In Bezug dazu lebten in Deutschland im Jahr 201032033000 erwachsene Frauen [6] - somit befindet sich jede 55. Frau in onkologischen Versorgungsstrukturen aufgrund einer Mammakarzinomerkrankung. Mit Hinblick auf diese Zahlen wird schnell ersichtlich, dass die Betreuung der Patientin mit einem Mammakarzinom eine enorme gesundheitsökonomische Relevanz besitzt - dies sowohl in der adjuvanten als auch palliativen Situation.

\section{Überblick der gesundheitsökonomischen Aspekte der individualisierten Therapieentscheidung \\ $\nabla$}

Die individualisierte Therapie der Patientin mit einem Mammakarzinom, die derzeit sowohl die Forschung als auch den klinischen Alltag bestimmt, ist für die Gesundheitsökonomie besonders relevant, da sie einerseits durch den gezielteren Einsatz die Effektivität erhöht und somit Folgekosten durch die Vermeidung von Rezidiven und metastasierten Verläufen senkt, andererseits durch die Reduktion von Übertherapien monetäre Ressourcen schont - sowohl in Folge der vermiedenen direkten Kosten für die Systemtherapien und supportiven Behandlungen, andererseits indirekt durch die Vermeidung von Fahrten zu Kliniken und Praxen, Wartezeiten, Lebensqualitätsverlust und die frühere Wiedereingliederung in der Arbeitswelt mit dem dazugehörigen Anteil am Bruttosozialprodukt.

Gerade die medikamentösen Therapien verursachen enorme Kosten. Seit dem Jahre 2004 liegen die Ausgaben für Arzneimittel über den Kosten für die ärztliche Behandlung. Eine Ursache der höheren Ausgaben sind die Preise der neu zugelassenen Medikamente der letzten Jahre, insbesondere in der Onkologie. Während Tamoxifen bei Markteintritt einen Preis von 100 \$ pro Monat in den USA hatte, liegen nun die Preise deutlich höher, wie z. B. Nab-Paclitaxel mit über 7500 \$ pro Monat [10]. Zudem erhalten auch mehr Patientinnen aufgrund besserer supportiver Therapien und optimiertem Nebenwirkungsmanagement Systemtherapien über einen längeren Zeitraum. Aktuell werden in den USA 15 Milliarden US \$ pro Jahr für die Therapie des Mammakarzinoms ausgegeben. Rechnerisch werden es im Jahre 2020 fast 25 Milliarden US \$ sein [10].

Bisher wird in Studien ein Kollektiv mit einer Therapie gegenüber einer anderen Therapie bzw. keiner Therapie behandelt, und folgend der Benefit anhand der Steigerung des krankheitsfreien oder des Gesamtüberlebens beurteilt. Bleibt die Patientin gesund, besteht die Möglichkeit, dass die Therapie gewirkt hat, und sie somit keinen Rückfall bekommen hat. Jedoch besteht auch die Option, dass die Patientin ohnehin keinen Rückfall bekommen hätte und die Therapie eine Übertherapie darstellt ( Abb. 1). Somit ist die klare Forderung, vorab die Patientinnen zu identifizieren, die eine Therapie brauchen, bei denen die Therapie wirkt oder bei denen spezifische Nebenwirkungen auftreten können. Dementsprechend sind Testsysteme, welche die Entscheidung für oder gegen eine medikamentöse Therapie unterstützen, zukünftig besonders relevant.

Zunehmend in den Fokus der Therapieentscheidung rückt die molekulare Klassifikation des Mammakarzinoms in Subtypen, wie Luminal A, Luminal B, Her2-positiv und Basal-like [7, 17, 18, 27]. Die bestehende Datenlage zeigt deutlich, dass die Klassifizierung in die molekularen Subtypen prognostisch relevant ist und Therapieentscheidungen auf Basis dieser Klassifikation getroffen werden können. Da jedoch diese molekulare Diagnostik noch nicht flächendeckend möglich ist, werden aktuell verfügbare klinische bzw. pathologische Ei- 


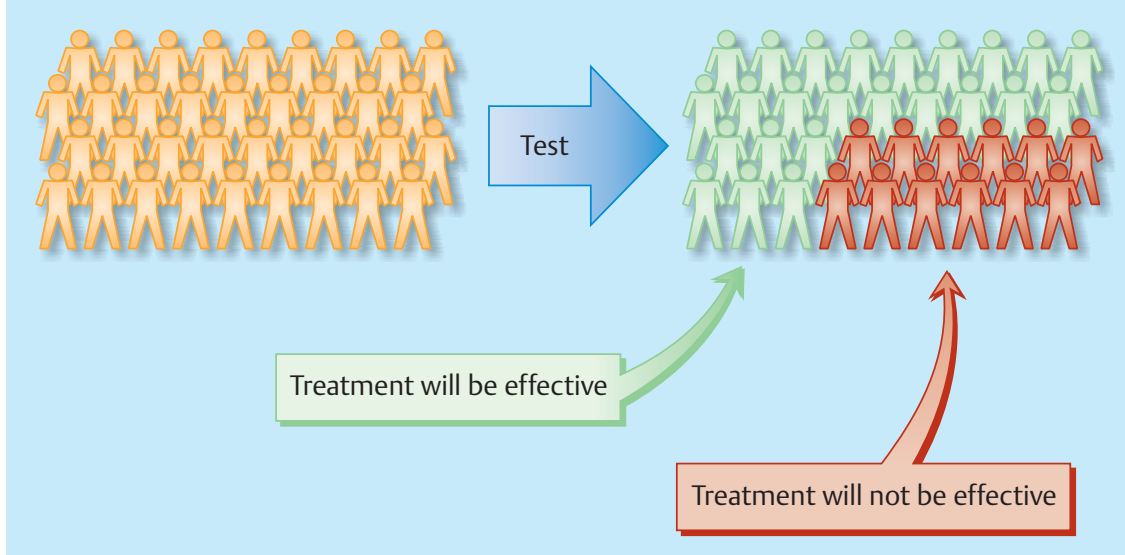

Fig. 1 The importance of the early identification of patients who will respond or not respond to a specific therapy [33].

cation. However, this type of molecular diagnostics is not yet comprehensively possible, and so currently available clinical or pathological characteristics are linked to subtypes (e.g. ER/PR positive, G1, low Ki-67 status, HER2/neu-negative for luminal A). Other possible tests include creating gene expression profiles from the tumour, gene copy variations, creating gene expression profiles of healthy stromal cells, epigenetic chips, miRNA chips, SNP chips and proteomics (e.g. PAI) and SNP chips to investigate germline DNA. The Oncotype DX ${ }^{\circledR}$, MammaPrint ${ }^{\circledR}$ or Femtelle ${ }^{\circledR}$ tests have a huge potential in this context, although we need to await the results of prospective trials for the former.

Calculation programmes are also still very useful. While they are not molecular tests, they can be used to calculate the prognosis of a patient with or without treatment using clinical and pathological factors, and to support individual treatment decisions. Examples of such calculation programmes include Adjuvant! Online, PREDICT and PREDICT Plus [22,29,31].

- Table 1 provides an overview of the options available to guide individualised treatment decisions.

But the question quickly arises as to who should pay for these tests. At the moment, many tests are paid "out of pocket", i.e., affected patients in Germany pay for the tests themselves. The certified breast cancer centres in Germany are currently underfunded and barely capable of absorbing further costs [3,4]. Health economic evaluations should be used to evaluate these tests and their impact on healthcare services. A cost-utility analysis can be used to assess the effects of a measure (in this case, the tests) and to weigh their importance [19]. The results of the costutility analyses can be used in international comparisons and in comparisons with other interventions and to support decisions by funding agencies whether to finance tests. Internationally, quality-adjusted life years (QALYs) are the most common measure used for such assessments; QALYs are a measure of the number of additional years obtained by an intervention, with one year lived in perfect health assigned the value of 1.0 ; the value is adjusted accordingly to reflect quality of life. No figures have been defined for Germany, as decisions on tests are made by the Federal Joint Committee (Gemeinsamer Bundesausschuss) after their assessment by the IQWiG (the Institute for Quality and Efficiency in Healthcare). In the USA, costs below $\$ 50000$ per QALY are considered cost-effective and costs over $\$ 100000$ as very high. In the latter case, approval is only given after a detailed clinical justification. When the costs of an intervention are between $\$ 50000$ and $\$ 100000$ a detailed assessment is made which in- genschaften in Bezug zu den Subtypen gebracht (z.B. ER/PR-positiv, G1, Ki67-niedrig, Her2neu-negativ entsprechend für Luminal A). Weitere mögliche Testverfahren sind u.a. Genexpressionsprofile aus dem Tumor, Genkopienvariationen, Genexpressionsprofile aus gesundem Stroma, Epigenetik-Chips, miRNA-Chips, SNP-Chips und Proteomics (z.B. PAI) wie auch SNP-Chips zur Untersuchung der Keimbahn-DNA. Ein großes Potenzial haben hier Verfahren wie Oncotype DX ${ }^{\circledR}$, MammaPrint ${ }^{\circledR}$ oder Femtelle ${ }^{\circledR}$, wobei für erstere noch prospektive Studienergebnisse abgewartet werden sollten.

Zudem sollten nicht die Berechnungsprogramme vergessen werden, die zwar keine molekularen Testverfahren darstellen, jedoch auf Basis klinischer und pathologischer Eigenschaften eine Berechnung der Prognose einer Patientin ohne und mit Therapie ermöglichen, und so individuelle Therapieentscheidungen unterstützen - Beispiele sind Adjuvant! online, PREDICT oder PREDICT Plus [22,29,31].

Eine Übersicht der Möglichkeiten individueller Therapieentscheidungen wird in $\bigcirc$ Tab. 1 präsentiert.

Es stellt sich jedoch schnell die Frage, wer die Kosten für diese Tests bezahlt. Aktuell werden zahlreiche Tests Out-of-Pocket finanziert, d.h. die betroffenen Patientinnen in Deutschland zahlen es selbst. Die zertifizierten Brustkrebszentren sind derzeit bereits unterfinanziert und können weitere Kosten kaum auffangen [3,4]. Anhand gesundheitsökonomischer Evaluationen können diese Tests auf den Prüfstand gestellt und die Auswirkungen auf das Gesundheitswesen betrachtet werden. Kosten-Nutzwert-Analysen sind in der Lage, alle Wirkungen einer Maßnahme (in diesem Fall Testsysteme) durch ein geeignetes Gewichtungssystem zu berücksichtigen [19]. Die Ergebnisse dieser Analysen erlauben internationale Vergleiche und Vergleiche mit anderen Interventionen und stützen die Entscheidungen der Kostenträger, eine Maßnahme zu finanzieren. International werden die qualitätsadjustierten Lebensjahre (QALYs) am häufigsten verwendet, d.h. wie viel monetäre Ressourcen müssen ausgeben werden, um ein Lebensjahr mit 100\%iger Gesundheit bzw. Lebensqualität zu erreichen. Für Deutschland gibt es keine definierten Grenzwerte, da diese Entscheidungen durch den Gemeinsamen Bundesausschuss nach Bewertung durch das IQWiG erfolgen. In den USA werden Kosten unter 50000 \$ pro QALY als günstig bzw. kosteneffektiv angesehen und Kosten über $100000 \$$ als sehr hoch bewertet. Hier erfolgt eine Zustimmung nur bei genauer klinischer Rechtfertigung. Bei Kosten von 50000 bis 100000 \$ erfolgt eine detaillierte Beurteilung nach klarer Darstellung des Benefits. Beispiele für Kosten pro QALY sind in der $\odot$ Tab. 2 dargestellt. 
Table 1 Range of options used to make individualised treatment decisions for patients with breast cancer.

\begin{tabular}{|c|c|c|c|c|c|}
\hline & Relevance & Test method & $\begin{array}{l}\text { Material used } \\
\text { for testing }\end{array}$ & Possible indication & Recommendation \\
\hline Prevention & $\begin{array}{l}\text { prevention of breast } \\
\text { and/or ovarian cancer }\end{array}$ & $\begin{array}{l}\text { BRCA } 1 / 2 \text { mutation } \\
\text { analysis }\end{array}$ & blood & $\begin{array}{l}\text { familial risk of breast } \\
\text { or ovarian cancer }\end{array}$ & $\begin{array}{l}\text { in accordance with } \\
\text { S3 Guidelines }\end{array}$ \\
\hline \multirow[t]{3}{*}{$\begin{array}{l}\text { Prediction of } \\
\text { effectiveness of } \\
\text { drugs/side effects }\end{array}$} & $\begin{array}{l}\text { effectiveness of endo- } \\
\text { crine therapy with } \\
\text { tamoxifen }\end{array}$ & CPYP2D6 analysis & blood & $\begin{array}{l}\text { patients with breast } \\
\text { cancer and tamoxifen } \\
\text { therapy }\end{array}$ & $\begin{array}{l}\text { currently no recommen- } \\
\text { dation }\end{array}$ \\
\hline & $\begin{array}{l}\text { effectiveness of HER2- } \\
\text { targeted therapies }\end{array}$ & $\begin{array}{l}\text { HER2/neu analysis } \\
\text { using IHC, FISH, CISH }\end{array}$ & $\begin{array}{l}\text { formalin-fixed } \\
\text { tumour tissue }\end{array}$ & $\begin{array}{l}\text { all patients with } \\
\text { breast cancer }\end{array}$ & $\begin{array}{l}\text { in accordance with } \\
\text { S3 Guidelines (level A } \\
\text { recommendation) }\end{array}$ \\
\hline & $\begin{array}{l}\text { prevention of toxicity } \\
\text { for } 5 \text {-FU/capecitabine } \\
\text { therapy }\end{array}$ & $\begin{array}{l}\text { DPYD*2A mutation } \\
\text { analysis }\end{array}$ & blood & $\begin{array}{l}\text { planned therapy using } \\
\text { 5-FU/capecitabine } \\
\text { (no general recommen- } \\
\text { dation available) }\end{array}$ & $\begin{array}{l}\text { currently no general } \\
\text { recommendation available }\end{array}$ \\
\hline $\begin{array}{l}\text { Classification of } \\
\text { breast carcinoma }\end{array}$ & $\begin{array}{l}\text { determination of the } \\
\text { breast cancer subtype }\end{array}$ & $\begin{array}{l}\text { gene expression } \\
\text { analysis }\end{array}$ & $\begin{array}{l}\text { formalin-fixed } \\
\text { tumour tissue }\end{array}$ & $\begin{array}{l}\text { all patients with } \\
\text { breast cancer }\end{array}$ & $\begin{array}{l}\text { currently no general } \\
\text { recommendation available }\end{array}$ \\
\hline \multirow[t]{7}{*}{$\begin{array}{l}\text { Calculcation of prog- } \\
\text { nosis and estimation } \\
\text { of benefit of systemic } \\
\text { therapies }\end{array}$} & $\begin{array}{l}\text { calculation of prognosis } \\
\text { and therapy benefit }\end{array}$ & $\begin{array}{l}\text { Adjuvant! Online } \\
\text { (web-based prognos- } \\
\text { tic programme) }\end{array}$ & $\begin{array}{l}\text { clinical } \\
\text { parameters }\end{array}$ & $\begin{array}{l}\text { all patients with } \\
\text { breast cancer }\end{array}$ & $\begin{array}{l}\text { AGO: useful to estimate } \\
\text { benefit for individual } \\
\text { patients ( } \pm \text { ); not evaluated } \\
\text { in S3 Guidelines }\end{array}$ \\
\hline & & $\begin{array}{l}\text { PREDICT } \\
\text { (web-based prognos- } \\
\text { tic programme) }\end{array}$ & $\begin{array}{l}\text { clinical } \\
\text { parameters }\end{array}$ & $\begin{array}{l}\text { all patients with } \\
\text { breast cancer }\end{array}$ & $\begin{array}{l}\text { AGO: useful to estimate } \\
\text { benefit for individual } \\
\text { patients ( } \pm \text { ); not evaluated } \\
\text { in S3 Guidelines }\end{array}$ \\
\hline & & $\begin{array}{l}\text { PREDICT-Plus } \\
\text { (web-based prognos- } \\
\text { tic programme) }\end{array}$ & $\begin{array}{l}\text { clinical } \\
\text { parameters }\end{array}$ & $\begin{array}{l}\text { all patients with } \\
\text { HER2/neu-positive } \\
\text { breast cancer }\end{array}$ & $\begin{array}{l}\text { AGO: useful to estimate } \\
\text { benefit for individual } \\
\text { patients }( \pm) \text {; not evaluated } \\
\text { in S3 Guidelines }\end{array}$ \\
\hline & $\begin{array}{l}\text { calculation of prognosis } \\
\text { and estimation of ben- } \\
\text { efit of chemotherapy } \\
\text { and tamoxifen therapy }\end{array}$ & $\begin{array}{l}\text { Oncotype DX } \\
\text { 21-gene recurrence } \\
\text { score based on } \\
\text { qRT-PCR }\end{array}$ & $\begin{array}{l}\text { formalin-fixed } \\
\text { tumour tissue }\end{array}$ & $\begin{array}{l}\text { node-negative and } \\
\text { node-positive, } \\
\text { ER-positive patients }\end{array}$ & $\begin{array}{l}\text { AGO: useful to estimate } \\
\text { benefit for individual } \\
\text { patients }( \pm) ; \text { S3 Guidelines: } \\
\text { not recommended }\end{array}$ \\
\hline & $\begin{array}{l}\text { calculation of prognosis } \\
\text { and estimation of ben- } \\
\text { efit of chemotherapy }\end{array}$ & $\begin{array}{l}\text { MammaPrint }{ }^{\circledR} \\
70 \text {-gene assay using } \\
\text { DNA microarrays }\end{array}$ & $\begin{array}{l}\text { fresh frozen } \\
\text { tumour tissue }\end{array}$ & $\begin{array}{l}\text { node-negative } \\
\text { patients stage I-II }\end{array}$ & $\begin{array}{l}\text { AGO: useful to estimate } \\
\text { benefit for individual } \\
\text { patients }( \pm) \text {; } 53 \text { Guidelines: } \\
\text { not recommended }\end{array}$ \\
\hline & calculation of prognosis & $\begin{array}{l}\text { Endopredict }^{\circledR} \\
\text { q-RT-PCR }\end{array}$ & $\begin{array}{l}\text { formalin-fixed } \\
\text { tumour tissue }\end{array}$ & ER-positive patients & $\begin{array}{l}\text { AGO: useful to estimate } \\
\text { benefit for individual } \\
\text { patients }( \pm) \text {; } \$ 3 \text { Guidelines: } \\
\text { not recommended }\end{array}$ \\
\hline & $\begin{array}{l}\text { estimation of benefit } \\
\text { of chemotherapy }\end{array}$ & $\begin{array}{l}\text { Femtelle }^{\circledR} \\
\text { determination } \\
\text { of u-PA/PAI }\end{array}$ & $\begin{array}{l}\text { fresh frozen } \\
\text { tumour tissue }\end{array}$ & $\begin{array}{l}\text { node-negative patients } \\
\text { with breast cancer } \mathrm{G} 2 \text {, } \\
\text { HR+, HER2/neu-negative, } \\
>35 \text { years }\end{array}$ & $\begin{array}{l}\text { AGO: recommended (+); } \\
\text { S3 Guidelines: no general } \\
\text { recommendation (level 0) }\end{array}$ \\
\hline
\end{tabular}

cludes careful examination of the expected benefit. Table 2 shows examples of costs per QALY.

\section{Tests for Primary Prevention \\ $\nabla$}

Tests are used more commonly to plan therapy than many people are initially aware of. The classic example is testing for BRCA-1/2 mutation. With a cost of $5400 \$$ per QALY this is considered very cost-effective [10]. Prophylactic measures are taken if a mutation is identified. This helps save costs later on by preventing the development of primary breast cancer, recurrence or metastatic disease. Health economic evaluations of the benefits of this test are also available. Grann et al. [2] investigated the cost-effectiveness of intensified screening using mammography and/or MRT compared to prophylactic mastectomy and/or ovariectomy compared to chemotherapeutic prevention in a group of women with the mutation but without disease. Prophylactic ovariectomy in
Table 2 QALYs in breast cancer therapy (2010, USD) [10].

\begin{tabular}{|c|c|}
\hline Intervention & $\begin{array}{l}\text { Incremental } \\
\text { cost-effectiveness } \\
\text { ratio (ICER) }\end{array}$ \\
\hline BRCA- $1 / 2$ test (age $\geq 35$; familial history) & \$5400/QALY \\
\hline Raloxifen to reduce breast cancer risk (age 55) & $\$ 22000 /$ QALY \\
\hline $\begin{array}{l}\text { Letrozole vs. anastrozole } \\
\text { (adjuvant, post-menopausal, } \mathrm{HR}+\text { ) }\end{array}$ & $\$ 26000 / Q A L Y$ \\
\hline Lapatinib plus capecitabine vs. capecitabine & $\$ 170000 / \mathrm{QALY}$ \\
\hline $\begin{array}{l}\text { Annual screening using MRT vs. mammography } \\
\text { (BRCA 1) }\end{array}$ & $\$ 210000 / \mathrm{QALY}$ \\
\hline $\begin{array}{l}\text { Bevacizumab plus paclitaxel vs. paclitaxel } \\
\text { (metastatic setting) }\end{array}$ & $\$ 280000 / \mathrm{QALY}$ \\
\hline $\begin{array}{l}\text { Partial breast irradiation vs. complete breast } \\
\text { irradiation (stage I, ER +, postmenopausal) }\end{array}$ & $\$ 730000 / \mathrm{QALY}$ \\
\hline Digital mammography screening vs. film (age $\geq 40$ & $\$ 930000 / Q A L Y$ \\
\hline
\end{tabular}


women with BRCA-1 mutation as the sole measure was associated with a cost of $\$ 1741$ per QALY and thus predominated compared to the combination of both prophylactic operations and to all other options. For women with BRCA-2 mutation, prophylactic mastectomy was the most cost-effective measure (\$5062/QALY). Overall, both types of prophylactic surgical interventions offered a better QALY compared to screening and chemotherapeutic prevention. It is therefore regrettable that these surgical interventions are currently not adequately reimbursed in Germany. For a subcutaneous mastectomy with subpectoral bilateral implantation of prostheses in a woman with BRCA-1 mutation (DRG J24B [2009]), the Gynaecological Hospital of the University Clinic of Erlangen receives $€ 4191.87$ in total (cost-unit accounting) compared to the actual cost of the intervention of $€ 7097.17$ (total: $€-2905.30$ ). This DRG does not change even if a decision is taken to carry out bilateral synchronous adnexectomy to benefit the patient and avoid a second surgical intervention; the reimbursement remains the same, despite the higher costs incurred.

\section{Diagnostic Tests}

$\nabla$

Another example in routine clinical practice is the HER2/neu test to identify patients who will respond to anti-HER2 therapy (e.g. trastuzumab, lapatinib). Many people are not aware that even the smallest changes in the sensitivity and specificity of different diagnostic methods may represent immense costs for healthcare services. If a patient tests false-negative, she will not receive therapy; the treatment of recurrent cancer and/or metastasis due to the false-negative test will generate additional costs. If the patient tests false-positive, the cost-intensive treatment $\$ 27446$ per adjuvant patient in the USA; approx. $€ 44000$ per adjuvant patient in Germany) generates additional unnecessary costs [16, 20]. A review of the literature was recently published which included an analysis of 46 studies [16]. Immunohistochemistry (IHC) was compared with tests such as fluorescence in situ hybridisation (FISH), chromogenic in situ hybridisation (CISH) and silver in situ hybridisation (SISH) and the respective sensitivities and specificities were compared. A total of 5 different scenarios were analysed (primary FISH, primary CISH, primary SISH, IHC with confirmation using FISH for $2+$, IHC and confirmation using FISH for $2+$ and $3+$ ). The benefit obtained with trastuzumab therapy was assumed to be 1.18 QALYs. Even though the in situ hybridisation methods were initially significantly more expensive ( \$ 418 vs. \$ 119 for IHC), the primary FISH test almost always performed better compared to a stepwise procedure using primary immunohistochemistry. None of the studies was able to show that IHC followed by FISH for 2+ was the most cost-effective option, although this combination is the current standard in Germany. All of the methods (IHC, FISH and CISH) have been approved for testing. As tests are usually done in the context of a DRG, costs which are used to justify the current standard do play an important role. In the longer term, it would be in the interests of funding agencies and healthcare services to provide adequate funding for the best test methods as this could significantly reduce follow-up costs. This is even more important when considering future developments such as pertuzumab and T-DM1 as well as potential dual anti-HER2 therapies.

\section{Testverfahren in der primären Prävention}

\section{$\nabla$}

Testverfahren zur Planung einer Therapie werden häufiger eingesetzt, als zunächst bewusst ist. Das klassische Beispiel ist die Testung auf eine BRCA-1/2-Mutation. Diese wird bei Kosten von $5400 \$$ pro QALY als absolut kosteneffektiv angesehen [10]. Bei Identifikation einer Mutation können prophylaktische Maßnahmen ergriffen und somit sowohl Folgekosten durch die Verhinderung einer primären Mammakarzinomerkrankung als auch rezidivierende oder metastasierende Verläufe vermieden werden. Hierzu sind auch gesundheitsökonomische Evaluationen vorhanden. Grann und Kollegen [2] untersuchten die Kosteneffektivität einer intensivierten Früherkennung mit Mammografie und/oder MRT im Vergleich zur prophylaktischen Mastektomie und/oder Ovarektomie im Vergleich zur Chemoprävention in einer Kohorte von nicht erkrankten Mutationsträgerinnen. Die prophylaktische Ovarektomie für BRCA-1-Mutationsträgerinnen war als alleinige Maßnahme mit Kosten von 1741 \$ pro QALY dominant gegenüber der Kombination beider prophylaktischen Operationen und allen weiteren Optionen. Für BRCA-2-Mutationsträgerinnen war die prophylaktische Mastektomie die kosteneffektivste Maßnahme (5062 \$/QALY). Insgesamt dominierten beide Arten von prophylaktischen Operationen im Vergleich zur Früherkennung und Chemoprävention. Dementsprechend ist es bedauerlich, dass diese derzeit in Deutschland nicht adäquat vergütet werden. So zeigte die Kostenträgerrechnung der Frauenklinik des Universitätsklinikums Erlangen für die subkutane Mastektomie mit Prothesenimplantation subpektoral beidseits im Falle einer BRCA-1-Mutationsträgerin (DRG J24B [2009]) einen Gesamterlös von 4191,87€ bei Kosten von 7097,17 € (Ergebnis $-2905,30 €)$. Wird zugunsten der Patientin und zur Vermeidung eines Zweiteingriffs die beidseitige Adnexektomie synchron durchgeführt, ändert sich die DRG nicht und der Erlös bleibt bei weiteren Mehrkosten der gleiche.

\section{Testverfahren in der Diagnostik \\ $\nabla$}

Ein weiteres Beispiel der täglichen Praxis ist die Her2neu-Testung zur Identifikation von Patientinnen für eine Anti-Her2-Therapie (z.B. Trastuzumab, Lapatinib). Was jedoch selten bewusst wird, ist die Tatsache, dass kleinste Veränderungen der Sensitivität und Spezifität der unterschiedlichen diagnostischen Verfahren immense Kosten für das Gesundheitswesen bedeuten können. Wird die Patientin falsch negativ getestet, erhält sie keine Therapie und es entstehen Kosten für mögliche Rezidive und/oder Metastasen. Wird sie falsch positiv getestet, entstehen unnötige Kosten durch die Therapie selbst, die kostenintensiv ist (27446\$ pro adjuvante Patientin in den USA; ca. $44000 €$ pro adjuvante Patientin in Deutschland) $[16,20]$. Hierzu wurde ein Literaturreview mit der Analyse von 46 Studien kürzlich publiziert [16]. Es wurde die Immunhistochemie (IHC) mit Testverfahren wie Fluoreszenz-in-situ-Hybridisierung (FISH), chromogene In-situ-Hybridisierung (CISH) und Silver-in-situ-Hybridisierung (SISH) verglichen und die jeweilige Sensitivität und Spezifität berücksichtigt. Insgesamt wurden 5 Szenarien analysiert (primär FISH, primär CISH, primär SISH, IHC und Bestätigung durch FISH bei 2+, IHC und Bestätigung durch FISH bei 2+ und 3+). Der Benefit durch eine adäquate Trastuzumab-Therapie wurde mit 1,18 QALYs angenommen. Auch wenn die Verfahren der In-situ-Hybridisierung zunächst deutlich teurer waren ( 418 \$ vs. 119 \$ für die IHC), war die primäre FISHTestung nahezu immer dominanter als das stufenweise Vorgehen mit primärer Immunhistochemie. Keine der Studien zeigte, dass IHC gefolgt von FISH bei 2+ die kosteneffektivste Option ist, obwohl dieses der übliche Standard in Deutschland darstellt. Zugelassen zur Testung 


\section{Tests for Supportive Therapy}

$\nabla$

When evaluating predictive tests, it is also important to take account of tests which can be used to predict the specific side effects of therapies, as these can also involve high follow-up costs. Current studies have focussed on pharmacogenetic investigations which predict the rate of neutropenias occurring during chemotherapy or the occurrence of arthralgia during therapies with aromatase inhibitors. The DPYD*2A mutation, which is present in around $3 \%$ of the Caucasian population, is of particular interest in this context. Therapy with 5-FU or capecitabine can result in extremely serious bone-marrow toxicity in this segment of the population or even be lethal. The investigation into the cost-effectiveness of genetic analysis for dihydropyrimidine dehydrogenase deficiency (enzyme for the metabolisation of fluoropyrimidine) was done by genotyping 1700 patients [8]. The heterozygote variant was found in $1 \%$ of tested patients. Even though the costs of testing were initially high, the total costs were lower as follow-up costs could be avoided. By reducing the dosage, toxicity was reduced compared to the levels reported in the literature (toxicity $\geq$ level 3: 15 vs. $68 \%$; mortality 10 vs. $0 \%$ ).

\section{Tests for Adjuvant Systemic Therapies} $\nabla$

Indications for adjuvant systemic therapy are currently predominantly based on node status, HER2/neu status, hormone receptor status, grading and age at onset of disease [15]. The indication should be made by an interdisciplinary tumour conference. The patient's wishes, expectations and co-morbidities need to be taken into account [15]. The recent focus has been on tests which can be used to plan systemic therapy for patients with breast cancer. The best known of these tests are the Oncotype DX ${ }^{\circledR}$, Femtelle $^{\circledR}$ and Mammaprint ${ }^{\circledR}$ tests ( Table 1). When assessing the costs and health economic impact of these tests it is important to take the current costs of decision-making as the starting point. Quality-assured immunohistochemical investigation currently plays the most important role in this assessment. As testing in certified breast cancer centres is done on an inpatient basis, the current costs based on the German medical fee schedule are as follows:

- determination of oestrogen receptor expression:

$€ 61.20$ (4815 a ×3),

- determination of progesterone receptor expression:

$€ 61.20$ (4815 a ×3),

- determination of Ki-67 proliferation index: $€ 40.80$ (4815 a × 2),

- determination of HER2/neu status using immunohistochemisty: € 81.60 (4815 a ×4).

The total costs of immunohistochemistry are therefore $€ 244.80$. If FISH or CISH testing is found to be necessary (e.g., for patients who are HER2/neu2+), this will result in additional costs of $€ 260.37$ (€12.65 [4800] + €20.40 [4815] + €227.32 [4872×2]). The benefit of the new tests should therefore be measured against the prognostic and predictive factors obtained from established histopathological investigation and considered not just qualitatively but also with regard to the cost of testing.

The Oncoytpe DX ${ }^{\circledR}$ is a standardised RT-PCR which can be used to identify patients who are highly likely or highly unlikely to benefit from chemotherapy. To do this, the so-called recurrence score obtained from the gene expression of 21 different genes (16 car- sind alle Verfahren (IHC, FISH und CISH). Da die Testung meist im Rahmen der DRG erbracht wird, spielen Kosten eine Rolle, die den aktuellen Standard rechtfertigen. Es wäre jedoch langfristig gesehen im Sinne der Kostenträger bzw. des Gesundheitssystems, das beste Testverfahren adäquat zu finanzieren, um Folgekosten deutlich zu reduzieren. Noch bedeutsamer wird dies bei Betrachtung der zukünftigen Entwicklungen, wie Pertuzumab und T-DM1, als auch der Möglichkeit der dualen Anti-Her2-Therapien.

\section{Testverfahren in der supportiven Therapie}

In Bezug auf prädiktive Testverfahren dürfen die Tests nicht vergessen werden, welche spezifische Nebenwirkungen einer Therapie vorhersagen können, da diese zu hohen Folgekosten führen können. Aktuelle Untersuchungen konzentrieren sich auf pharmakogenetische Untersuchungen, welche z. B. die Rate an Neutropenien unter Chemotherapie oder auch das Auftreten von Arthralgien unter Aromatasehemmertherapie vorhersagen können. In diesem Zusammenhang ist die DPYD*2A-Mutation interessant, welche bei 3\% der kaukasischen Bevölkerung nachweisbar ist. Im Falle einer Therapie mit 5-FU oder Capecitabin kann dies neben schwersten Knochenmarkstoxizitäten letale Verläufe verursachen. Die Untersuchung der Kosteneffektivität der genetischen Analyse auf Dihdydropyrimidindehydrogenase-Defizienz (Enzym zur Verstoffwechselung von Fluoropyrimidine) wurde mittels der Genotypisierung von 1700 Patientinnen durchgeführt [8]. Die heterozygote Variante konnte bei $1 \%$ der Getesteten nachgewiesen werden. Auch wenn die Testkosten zunächst hoch waren, lagen die Gesamtkosten durch die Vermeidung von Folgekosten niedriger. Durch eine Dosisreduktion konnten aufgetretene Toxizitäten im Vergleich zur Literatur reduziert werden (Toxizität $\geq \operatorname{Grad} 3$ : 15 vs. $68 \%$; Todesfälle 10 vs. $0 \%$ ).

\section{Testverfahren für die adjuvante Systemtherapie} $\nabla$

Die Indikation für eine adjuvante Systemtherapie basiert derzeit insbesondere auf dem Nodalstatus, dem Her2neu-Status, dem Hormonrezeptorstatus, dem Grading und dem Erkrankungsalter [15]. Die Indikation sollte interdisziplinär im Rahmen einer Tumorkonferenz festgelegt werden. Sowohl Wünsche und Erwartungshaltung als auch Komorbiditäten der Patientin müssen hierbei berücksichtigt werden [15]. Aktuell rücken Testsysteme in den Fokus, welche die Planung der systemischen Therapie der Patientin mit einem Mammakarzinom unterstützen können. Die bekanntesten sind Oncotype DX ${ }^{\circledR}$, Femtelle ${ }^{\circledR}$ und Mammaprint ${ }^{\circledR}(\odot$ Tab. 1). Bei der Betrachtung der Kosten und gesundheitsökonomischen Auswirkungen dieser Testsysteme müssen die aktuellen Kosten der Entscheidungsfindung als Ausgangssituation betrachtet werden. Hier spielt die qualitätsgesicherte immunhistochemische Untersuchung die wesentliche Rolle. Da die Leistung in den zertifizierten Brustkrebszentren stationär erbracht wird, ergeben sich nach der GOÄ die folgenden Kosten:

- Bestimmung der Östrogenrezeptor-Expression:

$61,20 €(4815 \mathrm{a} \times 3)$,

- Bestimmung der Progesteronrezeptor-Expression:

$61,20 €(4815 \mathrm{a} \times 3)$,

- Bestimmung des Ki67-Proliferationsindexes:

$40,80 €(4815 \mathrm{a} \times 2)$,

- Bestimmung des HER2neu-Status mittels Immunhistochemie: $81,60 €(4815 \mathrm{a} \times 4)$. 
cinoma-associated genes and 5 reference genes) is calculated [21]. The test has been retrospectively clinically validated using samples and results of the NSABP B-14 trial. The test provides an individualised prognosis for the risk of distant recurrence after 10 years for node-negative ER+ patients who receive adjuvant therapy for 5 years with tamoxifen (NSABP B14) and an individualised prediction of the benefit of tamoxifen (NSABP B-14) and of chemotherapy for node-negative $\mathrm{HR}+$ patients (NSABP B-20). It can also be used to calculate the individualised prognosis and estimate the benefit of chemotherapy for node-positive HR+ patients based on the ECOG 2197 and SWOG 8814 trials [1]. If the costs of testing are taken into consideration, the question is whether this approach will save costs or generate additional costs. The results of cost-effectiveness analyses carried out in several countries are available for the Oncotype $\mathrm{DX}^{\circledR}$ test.

The cost-effectiveness of the test for node-negative ER+ patients with breast cancer compared to decision-making using conventional clinicopathological criteria (stratified according to the risk groups used by Adjuvant! Online) was recently calculated for the US healthcare system and presented at last year's ASCO conference [23]. In the investigated group, $47.3 \%$ of patients would receive chemotherapy if the decision for treatment was based on conventional assessments. In contrast, $40.3 \%$ of patients would receive chemotherapy if assessed using the Oncotype $\mathrm{DX}^{\circledR}$ test. A benefit of 0.19 life years $(95 \% \mathrm{CI} 0.09-0.32)$ and 0.16 QALYs (95\% CI 0.08-0.28) was calculated at a cost of \$16677 per QALY (95\% CI \$7613-37219) for treatment based on the Oncotype DX ${ }^{\circledR}$ test. If the indirect costs were also taken into account (e.g. waiting times for therapies, etc.), the costs were $\$ 10788$ per QALY, i.e., the test was cost-effective. However, not all results of American cost-effectiveness analyses can be applied to other countries due to the differences in healthcare systems and population-specific genetic variations.

Hall et al. published the results of a Markov decision model using data from the healthcare system in the United Kingdom [12]. Their study looked at a cohort of node-positive and hormone receptor-positive patients in the UK. Average patient age was around 60 years and DFS data were based on the SWOG 8814 trial. The model also took anthracycline-induced cardiomyopathy after chemotherapy into account. All costs were based on the NICE guidelines and the NHS reference costs for 2011. The results are shown in $\bullet$ Table 3. The authors also calculated the potential impact on the UK healthcare system. With the cost of chemotherapy per patient calculated as $£ 6243$, a total of $£ 49000000$ was spent annually in the UK without using the Oncotype DX ${ }^{\circledR}$ test. When costs were calculated based on the assumption that $70 \%$ of chemotherapies could be avoided with the Oncotype DX ${ }^{\circledR}$ test, it was found that savings of $£ 35000000$ could be generated annually. With a test cost of $£ 2576$ per patient, the total annual cost of testing would be $£ 20000000$. This would result in a total saving of $£ 14000000$ per year in the UK. These results must be qualified, however, by noting that the rate of avoidable chemotherapies may be too high (the rates reported in the literature are between 11.9 and $70.6 \%$ ), that no other tests were included in the calculation, that Adjuvant! Online (which is available free of charge) was not included either, and that the average patient age was given as 60 years - younger patients benefit significantly more from chemotherapy.

This prompts the question what impact testing would have on cost-effectiveness and on the German healthcare system. The impact on costs in Germany was recently calculated [5]. The study compared the cost-effectiveness of the Oncotype DX ${ }^{\circledR}$ test to the
Es entstehen somit Gesamtkosten von $244,80 €$ für die Immunhistochemie. Im Falle einer notwendigen FISH- oder CISH-Untersuchung (z. B. bei Her2neu 2+) entstehen weitere Kosten von $260,37 €(12,65 €$ $[4800]+20,40 €[4815]+227,32 €[4872 \times 2])$. Die neuen Testverfahren müssen sich somit nicht nur qualitativ, sondern auch in Hinblick auf die Testkosten mit den etablierten prognostischen bzw. prädiktiven Faktoren der histopathologischen Untersuchung messen.

Bei Oncoytpe DX ${ }^{\circledR}$ handelt es sich um eine standardisierte RT-PCR, die Patientinnen identifiziert, die mit hoher oder geringer Wahrscheinlichkeit von einer Chemotherapie profitieren. Hierbei wird der sogenannte Recurrence-Score aus der Genexpression von 21 verschiedenen Genen (16 karzinomassoziierte Gene und 5 Referenzgene) berechnet [21]. Dieses wurde anhand der Proben und Ergebnisse der NSABP-B-14-Studie retrospektiv klinisch validiert. Aktuell liefert das Testsystem eine individualisierte Prognose des Risikos für ein Fernrezidiv nach 10 Jahren für nodal-negative, ER+-Patientinnen, die 5 Jahre adjuvant Tamoxifen erhalten (NSABP B14), die individualisierte Prädiktion des Tamoxifen-Benefits (NSABP B14) und des Chemotherapie-Benefits für nodal-negative, HR+-Patientinnen (NSABP B20). Zudem kann es die individualisierte Prognose und Prädiktion des Chemotherapie-Benefits bei nodal-positiven HR+-Patientinnen auf Basis der ECOG-2197- und SWOG-8814-Studien kalkulieren [1]. Unter Berücksichtigung der Testkosten stellt sich die Frage, ob durch dieses Vorgehen Kosten eingespart werden oder Mehrkosten entstehen. Für Oncotype DX ${ }^{\circledR}$ existieren Ergebnisse von Kosten-Effektivitäts-Analysen aus zahlreichen Ländern.

Für die Perspektive des amerikanischen Gesundheitswesens liegt eine aktuelle Berechnung der Kosteneffektivität des Tests für nodalnegative, ER+-Mammakarzinompatientinnen im Vergleich zur Therapieentscheidung mittels klassischer klinisch-pathologischer Kriterien (entsprechend der Risikogruppen von Adjuvant! online) vor, die beim letztjährigen ASCO-Kongress präsentiert worden ist [23]. Mit der konventionellen Therapieentscheidung hätten 47,3\% der Patientinnen eine Chemotherapie erhalten. Mit Oncotype DX ${ }^{\circledR}$ waren es $40,3 \%$ der Patientinnen. Es wurde ein Gewinn von 0,19 Lebensjahren (95\%KI 0,09-0,32) und 0,16 QALYs (95\%-KI 0,08-0,28) bei Kosten von 16677 \$ pro QALY (95\%-KI 7613-37219 \$) für die Therapie nach Oncotype $\mathrm{DX}^{\circledR}$ berechnet. Unter Berücksichtigung der indirekten Kosten (z.B. Wartezeiten bei Therapien, etc.) lagen die Kosten bei 10788 \$ pro QALY - somit insgesamt eine kosteneffektive Maßnahme. Jedoch sind nicht alle Ergebnisse von amerikanischen Kosteneffektivitätsanalysen auf andere Länder übertragbar; einerseits aufgrund unterschiedlicher Gesundheitssysteme, anderseits ggf. aufgrund unterschiedlicher bevölkerungsspezifischer genetischer Variationen.

Hall und Kollegen publizierten ein Markov-Modell basierend auf der Sicht des englischen Gesundheitssystems [12]. Hierbei wurde eine Kohorte nodal-positiver und hormonrezeptorpositiver Patientinnen aus England verwendet. Das Durchschnittsalter lag bei 60 Jahren und die DFS-Daten basierten auf der SWOG-8814-Studie. Zudem wurde u.a. die anthrazyklininduzierte Kardiomyopathie im Falle einer Chemotherapie berücksichtigt. Alle Kosten beruhten auf den NICE Guidelines und den NHS-Referenzkosten für das Jahr 2011. Die - Tab. 3 präsentiert die Ergebnisse. Folgend berechneten die Autoren die möglichen Auswirkungen auf das englische Gesundheitswesen. Bei Kosten einer Chemotherapie pro Patientin von $6243 £$ werden $49000000 £$ pro Jahr ohne die Verwendung von Oncotype DX ${ }^{\circledR}$ für England aufgewendet. Mit der Annahme, dass Oncotype DX ${ }^{\circledR} 70 \%$ der Chemotherapien vermeiden kann, könnten Einsparungen von $35000000 £$ pro Jahr erzielt werden. Bei Testkosten von $2576 £$ würden demgegenüber $20000000 £$ Testkosten pro Jahr entstehen. Somit wären Gesamteinsparung von $14000000 £$ pro Jahr in England möglich. Einschränkend muss hier jedoch betont werden, dass die Rate an 
Table 3 Comparison of molecular tests based on cost-effectiveness analysis.

\begin{tabular}{|c|c|c|c|c|c|c|c|}
\hline & \multicolumn{4}{|l|}{ Oncotype DX ${ }^{\circledR}$} & \multicolumn{2}{|l|}{ MammaPrint $^{\circledR}$} & Femtelle $^{\circledR}$ \\
\hline $\begin{array}{l}\text { Current cost } \\
\text { of test in } \\
\text { Germany }\end{array}$ & \multicolumn{4}{|c|}{$\begin{array}{l}€ 3180 \text { (as at } 02 / 13 \text { ) } \\
\text { www.oncotypedx.de }\end{array}$} & \multicolumn{2}{|c|}{$\begin{array}{l}€ 2675.00 \text { (as at 02/13) } \\
\text { www.mammaprint.de }\end{array}$} & $\begin{array}{l}€ 200-350 \text { (as at } 02 / 13 \text { ) } \\
\text { www.femtelle.de }\end{array}$ \\
\hline Model & \multicolumn{2}{|l|}{ United Kingdom } & \multicolumn{2}{|l|}{ Germany } & \multicolumn{2}{|l|}{ USA } & Germany \\
\hline Cohort & \multicolumn{2}{|c|}{$\begin{array}{l}\text { breast cancer, node-positive, } \\
\text { hormone receptor-positive }\end{array}$} & \multicolumn{2}{|c|}{$\begin{array}{l}\text { breast cancer, node-negative } \\
\& \text { node-positive }(0-3), \\
\text { hormone receptor-positive }\end{array}$} & \multicolumn{2}{|c|}{$\begin{array}{l}\text { breast cancer, node-negative, } \\
\text { oestrogen receptor-positive }\end{array}$} & $\begin{array}{l}\text { breast cancer, G2, } \\
\text { node-negative, hormone } \\
\text { receptor-positive, HER2/ } \\
\text { neu-negative, > } 35 \text { years }\end{array}$ \\
\hline Comparison & $\begin{array}{l}\text { therapy based } \\
\text { on conventional } \\
\text { criteria }\end{array}$ & $\begin{array}{l}\text { decision for } \\
\text { therapy based } \\
\text { on Oncotype } \\
\text { DX }{ }^{\circledR} \text { test }\end{array}$ & $\begin{array}{l}\text { current clinical } \\
\text { practice }\end{array}$ & $\begin{array}{l}\text { decision for } \\
\text { therapy based } \\
\text { on Oncotype } \\
\text { DX }{ }^{\circledR} \text { test }\end{array}$ & $\begin{array}{l}\text { decision for } \\
\text { therapy based } \\
\text { on Oncotype } \\
\text { DX }{ }^{\circledR} \text { test }\end{array}$ & $\begin{array}{l}\text { decision for } \\
\text { therapy based } \\
\text { on Mamma- } \\
\text { Print }{ }^{\circledR} \text { test }\end{array}$ & $\begin{array}{l}\text { costs can be saved if } \\
\text { Femtelle }{ }^{\circledR} \text { is used for } \\
\text { the therapy decision } \\
\text { based on } 93 \text { patients }\end{array}$ \\
\hline Total costs & $£ 22270$ & £ 23130 & $€ 19830$ & $€ 19269$ & $\$ 27882$ & $\$ 21598$ & - \\
\hline Cost of test & - & $£ 2576$ & - & $€ 3180$ & $\$ 3975$ & $\$ 4200$ & $\$ 350$ \\
\hline $\begin{array}{l}\text { Incremental } \\
\text { costs }\end{array}$ & - & $£ 860$ & - & $€-561$ & - & $\$-6284$ & - \\
\hline Life years & 13.37 & 13.52 & 16.94 & 17.01 & - & - & - \\
\hline $\begin{array}{l}\text { Incremental } \\
\text { life years }\end{array}$ & - & 0.15 & - & 0.06 & - & - & - \\
\hline QALYs & 10.16 & 10.32 & 13.12 & 13.19 & 7.364 & 7.461 & - \\
\hline $\begin{array}{l}\text { Incremental } \\
\text { QALYs }\end{array}$ & - & 0.16 & - & 0.06 & - & 0.097 & - \\
\hline ICER per QALY & - & $£ 5529$ & - & $€-9350$ & $\$ 3786$ & $\$ 2895$ & - \\
\hline $\begin{array}{l}\text { Return-of-in- } \\
\text { vestment ratio }\end{array}$ & - & - & - & - & - & - & $8.4: 1$ \\
\hline Source & Hall et al., 2012 [ & & Blohmer et al., 2 & $3[5]$ & Yang et al., 20 & [32] & Jacobs et al., 2012 [14] \\
\hline
\end{tabular}

cost-effectiveness of current clinical practice for 366 patients with early-stage hormone receptor-positive breast cancer and 0-3 affected lymph nodes from 15 German centres. A model adapted to current clinical practice in Germany in accordance with IQWIG guidelines and based on a decision impact study was used [9]. The perspective selected for the model was that of the funding institutions. The model integrated life expectancy, quality-adjusted life expectancy, direct costs, rates of recurrence and the specific mortality rates for Germany. Before carrying out the tests, chemotherapy was recommended for $57.1 \%$ of patients. After the tests, this dropped to $46.4 \%$. In actual fact, $38.3 \%$ of patients underwent chemotherapy, as $12.3 \%$ of patients did not follow the recommendations obtained by testing. The calculated increase was 0.06 QALYs per patient at a cost of $€ 561$ - clearly, a preferable option (increased QALY and lower costs) ( Table 3). When the wider social impact was also factored in, including the costs of time off work for chemotherapy, a cost saving of $€ 1446$ was calculated. Sensitivity analysis showed that costs were below $€ 20000$ per additional QALY with a probability of $100 \%$ (with a $96 \%$ probability that costs per QALY were $<€ 5000$ ). From a health economic standpoint, once the data has been confirmed in prospective studies, this promises to have significant implications for Germany.

As regards the Mammaprint ${ }^{\circledR}$ test, a comparison of the different tests would be interesting. Yang et al. compared the Oncotype $\mathrm{DX}^{\circledR}$ test (test costs of $\$ 3975$ ) with the Mammaprint ${ }^{\circledR}$ test (test costs of $\$ 4200$ ) using a cohort of 1000 node-negative, oestrogen receptor-positive patients, again from the point of view of funding agencies [32]. They also included Adjuvant! Online in their study. $50 \%$ of patients underwent chemotherapy based on the differing assessments by Adjuvant! Online and the Oncotype $\mathrm{DX}^{\circledR}$ and Mammaprint ${ }^{\circledR}$ tests. The intermediary group was included in the high-risk group. Total costs for the Mammaprint ${ }^{\circledR}$ vermiedenen Chemotherapien ggf. zu hoch angesetzt wurde (in der Literatur werden Raten zwischen 11,9 und 70,6\% angegeben), keine weiteren Tests als auch Adjuvant! Online (welches kostenfrei zur Verfügung steht) berücksichtigt worden sind und das Durchschnittsalter bei 60 Jahren lag - jüngere Patientinnen profitieren deutlicher von einer Chemotherapie.

Es stellt sich die Frage, wie es sich mit der Kosteneffektivität für das deutsche Gesundheitswesen verhält. In einer kürzlich publizierten Arbeit wurde dieses für Deutschland berechnet [5]. Es wurde die Kosteneffektivität des Einsatzes von Oncotype DX ${ }^{\circledR}$ in der aktuellen klinischen Praxis bei 366 Patientinnen mit einem frühen, hormonrezeptorpositiven Mammakarzinom mit 0-3 befallenen Lymphknoten aus 15 deutschen Zentren kalkuliert. Hierzu wurde ein an die klinische Praxis in Deutschland und die IQWIG-Richtlinien angepasstes Modell verwendet, welches auf einer Decision-Impact-Studie beruhte [9]. Es wurde für das Modell die Perspektive der Kostenträger gewählt. Das Modell integrierte die Lebenserwartung, die qualitätsadjustierte Lebenserwartung, die direkten Kosten, die Rezidivraten und die deutschlandspezifischen Mortalitätsdaten. Vor der Durchführung des Tests wurde bei 57,1\% eine Chemotherapie empfohlen. Nach Durchführung waren es $46,4 \%$. Tatsächlich wurde eine Chemotherapie in 38,3\% der Patientin gegeben, da 12,3\% der Patientin nicht der Empfehlung nach Testdurchführung folgten. Es konnte ein Zugewinn von 0,06 QALYs pro Patientin bei einer Kostenersparnis von $561 €$ kalkuliert werden - eine absolut dominante Option (Gewinn an QALY als auch kosteneinsparend) ( Tab.3). Unter Berücksichtigung der gesellschaftlichen Perspektive mit der Einbeziehung der Kosten für den Arbeitsausfall unter Chemotherapie wurde eine Ersparnis von $1446 €$ berechnet. Die Sensitivitätsanalyse erbrachte eine Wahrscheinlichkeit von 100\%, dass pro gewonnenem QALY die Kosten unter $20000 €$ liegen (96\%ige Wahrscheinlichkeit der Kosten pro QALY $<5000 €$ ). Es handelt sich somit aus gesundheitsökonomischer 
test (costs of the test, treatment and follow-up) were calculated as $\$ 21598$ (Oncotype DX ${ }^{\circledR} \$ 27882$ ). The QALY was calculated as 7.461 and thus higher by 0.097 QALY compared to the Oncotype $\mathrm{DX}^{\circledR}$ (7.364). The calculated costs were $\$ 2895$ per QALY for the Mammaprint ${ }^{\circledR}$ test and $\$ 3786$ for the Oncotype DX ${ }^{\circledR}$ test ( $\triangle$ Table 3). The Mammaprint ${ }^{\circledR}$ test appears to be slightly more cost-effective, although both test methods were shown to be promising and cost-effective.

At present, the Breast Commission of the Arbeitsgemeinschaft Gynäkologische Onkologie e.V. (AGO [Working Group for Gynaecological Oncology]) only recommends the use of genetic tests such as Oncotype DX ${ }^{\circledR}$ and Mammaprint ${ }^{\circledR}$ on an individual basis (LoE 2b, GR B, AGO \pm ) [26]. Before recommending general use of these tests, the commission wants to wait for the results of prospective trials such as TAILOR-X and MINDACT. The current interdisciplinary S3 Guidelines for the diagnosis, treatment and follow-up of breast cancer has also commented on the test methods [15]. According to the S3 Guidelines, the Oncotype DX ${ }^{\circledR}$ test should be used where appropriate to assess the benefit of chemotherapy when conventional markers do not permit a clear classification of risk. Use of the test is therefore only recommended on an individual basis. As regards the MammaPrint ${ }^{\circledR}$ test, which was licensed for use as a prognostic test in 2007 by the U S Food and Drug Administration (FDA), it must be emphasised that no guidelines currently recommend the use of this test. It should also be noted that none of the existing guidelines include a systematic review of the literature on gene expression tests. It is not possible to rule out potential injury to patients (recurrence and metastatic disease which could have been prevented by chemotherapy). The evidence is therefore still insufficient to accurately assess the ratio between benefits and risks when using such tests. Further studies will be necessary to close the important gaps in our knowledge.

Testing for the biomarkers uPA and PAI can be done to avoid unnecessary chemotherapy in patients with primary breast cancer classified as medium risk (G2, N-, HR+, HER2/neu-, > 35 years). A prospective, multi-centre study found that use of these biomarkers in 93 patients prevented 35 chemotherapies or 12.1 years of chemotherapy application (calculation based on 210 cycles) [14]. Costs of $€ 221816$ for systemic therapy, $€ 25749$ for GCS-F and $\$ 34353$ for additional supportive therapies were saved (total savings: $\$ 281918$ ). With test costs of $\$ 350$ per patient, the return-of-investment ratio was 8.4:1 ( Table 3). The costs of side-effects, of short and long-term chemotherapyrelated morbidities and the cost savings achieved by avoiding inpatient stays and febrile neutropenia were not included, nor were absences from work due to effect of chemotherapy and the costs of the burden on the family; all of these would significantly increase the ratio in favour of testing.

However, in this era of gene expression profiles, it should not be forgotten that web-based prognostic tools are also available to calculate the prognosis and estimate the benefits of systemic therapy ( $\bullet$ Table $\mathbf{1}$ ). The web-based programme Adjuvant! Online was introduced in 2001 and offers a model to calculate patient prognosis [22]. The benefit of endocrine therapy compared to chemotherapy or a combination of both was calculated using data obtained from the Early Breast Cancer Trialists Collaborative Group und the Surveillance Epidemiology and End Results Program (SEER). The model was validated in several case-control studies. The PREDICT prognostic model, an online tool which calculates prognosis and estimates the benefit of treatment, was developed in the UK, based on data from 5694 breast cancer pa-
Sicht um ein bedeutsames Verfahren für Deutschland, sobald dieses durch Daten aus prospektiven Studien bestätigt wird.

In Bezug auf Mammaprint ${ }^{\circledR}$ wäre ein Vergleich der unterschiedlichen Testverfahren interessant. Yang und Kollegen verglichen Oncotype DX $^{\circledR}$ (Testkosten von $3975 \$$ ) mit Mammaprint ${ }^{\circledR}$ (Testkosten von $4200 \$$ ) anhand von 1000 nodal-negativen, östrogenrezeptorpositiven Patientinnen aus Sicht der Kostenträger [32]. Zudem integrierten sie Adjuvant! online. Bei einer unterschiedlichen Beurteilung durch Adjuvant! online und Oncotype DX ${ }^{\circledR}$ bzw. Mammaprint ${ }^{\circledR}$ erhielten $50 \%$ der Patientinnen eine Chemotherapie. Die intermediäre Gruppe wurde zu der High-Risk-Gruppe gerechnet. Für Mammaprint ${ }^{\circledR}$ wurden Gesamtkosten (Testverfahren, Therapie- und Folgekosten) von 21598 \$ berechnet (Oncotype DX ${ }^{\circledR} 27882$ \$). Die gewonnenen QALYs lagen mit 7,461 QALYs um 0,097 QALY höher als bei Oncotype DX ${ }^{\circledR}$ $(7,364)$. Die Kosten waren $2895 \$$ pro QALY für Mammaprint ${ }^{\circledR}$ und $3786 \$$ für Oncotype DX ${ }^{\circledR}\left(-\right.$ Tab. 3). Mammaprint ${ }^{\circledR}$ stellt sich etwas kosteneffektiver da, wobei beide Testverfahren in der Kalkulation kosteneffektiv und vielversprechend sind.

Aktuell wird der Einsatz genetischer Test, wie Oncotype DX ${ }^{\circledR}$ und Mammaprint ${ }^{\circledR}$, von der Kommission Mamma der Arbeitsgemeinschaft Gynäkologische Onkologie e.V. (AGO) nur auf individueller Basis empfohlen (LoE 2b, GR B, AGO \pm ) [26]. Vor einem generellen Einsatz sollten noch die Ergebnisse prospektiver Studien, wie TAILOR-X und MINDACT abgewartet werden. Auch die aktuelle interdisziplinäre S3-Leitlinie für die Diagnostik, Therapie und Nachsorge des Mammakarzinoms nimmt zu den Testverfahren Stellung [15]. Oncotype $\mathrm{DX}^{\circledR}$ darf entsprechend angewandt werden, um den Benefit einer Chemotherapie abzuschätzen, wenn die herkömmlichen Marker keine eindeutige Risikozuordnung erlauben. Somit ist der Einsatz nur individuell zu sehen. In Bezug auf MammaPrint ${ }^{\circledR}$, welcher im Jahr 2007 als prognostischer Test von der U.S. Food and Drug Administration (FDA) zugelassen wurde, wird jedoch betont, dass dieser aktuell in keiner Leitlinien empfohlen wird. Es wird zudem darauf hingewiesen, dass keine der bestehenden Leitlinien eine systemische Literaturrecherche zum Thema der Genexpressionstests vorweist. Insgesamt lässt sich ein potenzieller Schaden für Patientinnen nicht ausschließen (Rezidive und Metastasen, welche durch eine Chemotherapie hätten verhindert werden können). Somit reicht die Evidenz nicht aus, das Verhältnis von Nutzen und Risiko durch die Anwendung solcher Tests abzuschätzen. Es wird auf die Notwendigkeit weiterer Studien hingewiesen, um wichtige Informationslücken zu schließen.

Die Bestimmung von uPA und PAI kann Chemotherapien bei Patientinnen mit einem primären Mammakarzinom mittleren Risikos vermeiden (G2, N-, HR+, Her2neu-, > 35 Jahre). Im Rahmen einer prospektiven, multizentrischen Studie konnten durch den Einsatz des Tests bei 93 Patientinnen 35 Therapien bzw. bei 210 Zyklen 12,1 Jahre Chemotherapieapplikationszeit vermieden werden [14]. Es wurden zudem Kosten von $221816 €$ für Systemtherapien, $25749 €$ für GCS-F, und $34353 \$$ für weitere Begleittherapien eingespart (gesamt 281918 \$). Bei Testkosten von 350 \$ pro Patientin lag die Return-ofInvestment-Ratio bei 8,4:1 ( Tab.3). Kosten für Nebenwirkungen, kurz und langzeitig auftretende chemotherapieassoziierte Morbiditäten, Vermeidung von Hospitalisierungen und febrilen Neutropenien, Krankschreibungen mit Wegbleiben am Arbeitsplatz als auch die Kosten für familiäre Belastungen wurden nicht berücksichtigen und würden die Ratio weiter deutlich zugunsten des Tests erhöhen. Dennoch darf im Zeitalter der Genexpressionsprofile nicht vergessen werden, dass auch internetbasierte Berechnungsprogramme zur Abschätzung der Prognose und des Benefits einer Systemtherapie zur Verfügung stehen ( Tab. 1). Im Jahr 2001 wurde Adjuvant! als online Modell zur Berechnung der Prognose eingeführt [22]. Folgend war die Kalkulation des Therapievorteils einer endokrinen Therapie, einer 
tients for the years 1999 to 2003 [29]. The model has been validated in various independent cohorts and compared with the Adjuvant! model. Both models accurately calculated overall survival and breast cancer-specific survival [30]. However neither of the models included HER2/neu status in their calculations and therefore also ignored the potential benefit of HER2-targeted therapy. The prognostic effect of HER2/neu status was subsequently determined and included in the PREDICT model, using the data of 10179 patients with breast cancer from 14 trials of the Breast Cancer Association Consortium (BCAC). This PREDICT Plus model was validated using the data of 1613 patients with early-stage breast cancer [31]. All 3 calculation programmes were found to be reliable, although PREDICT Plus was much better at predicting overall survival and breast cancer-associated survival of HER2/neu-positive patients. As these prognostic tools are available free of charge, use of these programmes could be extremely cost-effective. However, as yet only a limited number of health economic evaluations of these programmes are available (3 publications on Adjuvant! Online; none on PREDICT or PREDICT Plus). Retèl et al. compared the cost-effectiveness of treatment decisions based on the St. Gallen consensus, Adjuvant! Online and the MammaPrint ${ }^{\circledR}$ test using a Markov decision model and the analysis of 305 tumour samples using 70-gene signature [24]. Outcomes of all 3 strategies were basically comparable, although decision-making based on the St. Gallen consensus was the most cost-intensive. Total healthcare costs were $€ 28045$ with the MammaPrint ${ }^{\circledR}$ test, $€ 35475$ with the St. Gallen consensus and $€ 26915$ using Adjuvant! Online. Quality-adjusted survival was highest with the 70 -gene signature (12.44 vs. 12.20 with Adjuvant! Online and 11.24 using the St. Gallen consensus). The cost per QALY using the MammaPrint ${ }^{\circledR}$ test compared to the Adjuvant! programme was $€ 4614$. A comparison of the MammaPrint $^{\circledR}$ test with the St. Gallen criteria found that the MammaPrint ${ }^{\circledR}$ test resulted in more QALYs at a lower cost. In this model, the 70-gene signature was the most cost-effective strategy. More health economic models to evaluate the cost-effectiveness of web-based prognostic tools compared to molecular tests are necessary; such studies would need to include an evaluation of PREDICT and PREDICT Plus.

\section{Tests from the Point of View of Patients \\ $\nabla$}

One question does arise with regard to the breast cancer-related tests discussed above and their use to guide treatment decisions: do patients actually want them? Genetic investigations are becoming increasingly important in the decision-making of tumour conferences. One study investigated 278 patients with cancer (19\% patients with breast cancer) in a curative $(n=153)$ or a palliative setting $(n=125)$ and asked them about the potential use of pharmacogenetic tests [13]. In an adjuvant setting, 99\% of surveyed patients wanted a test which could identify the benefits of chemotherapy. Patients were prepared to pay $\$ 2000$ on average (range \$0-25000) themselves and found a waiting time of 21 days acceptable. In a palliative setting, $98 \%$ of surveyed patients wished for a test which could predict serious toxicities on an individual basis. Patients were prepared to pay $\$ 1000$ (\$0-15000) themselves and to accept a waiting time of 14 days. Patient acceptance and the desire for such tests is consequently very high, although $20 \%$ of patients surveyed in an adjuvant setting and $22 \%$ of patients in a palliative setting reported that they did not entirely understand the importance of pharmacogenetic tests.
Chemotherapie und der Kombination beider auf Basis der Daten der Early Breast Cancer Trialists Collaborative Group und des Surveillance Epidemiology and End Results Program (SEER) verfügbar. Das Modell wurde in mehreren Fall-Kontroll-Studien validiert. In England wurde auf Basis von 5694 Mammakarzinompatientinnen der Jahre 1999 bis 2003 PREDICT als Online-Modell für die Kalkulation der Prognose und des Therapiebenefits entwickelt [29]. Auch dieses Modell wurde in unabhängigen Kohorten validiert und mit Adjuvant! verglichen. Beide Modelle konnten hier akkurat sowohl das Gesamtüberleben als auch das brustkrebsspezifische Überleben kalkulieren [30]. Jedoch berücksichtigen beide Modelle nicht den Her2neu-Status und somit nicht den Vorteil einer Her2-zielgerichteten Therapie. Anhand von 10179 Mammakarzinompatientinnen aus 14 Studien des Breast Cancer Association Consortiums (BCAC) wurde der prognostische Effekt des Her2neu-Status ermittelt und in das PREDICT-Modell integriert. Das nun vorliegende PREDICT-Plus-Modell wurde mittels 1613 Patientinnen mit einem frühen Mammakarzinom validiert [31]. Insgesamt zeigten sich alle 3 genannten Berechnungsprogramme zuverlässig, wobei PREDICT Plus deutlich besser das Gesamtüberleben und das mammakarzinomassoziierte Überleben für Her2neu-positive Patientinnen vorhersagen konnte. Da die genannten Berechnungsprogramme kostenfrei sind, könnte eine bedeutsame Kosteneffektivität vorhanden sein, auch wenn hierzu wenig gesundheitsökonomische Evaluationen zur Verfügung stehen (3 Publikationen zu Adjuvant! online; keine zu PREDICT und PREDICT Plus). Retèl und Kollegen verglichen die Kosteneffektivität der Therapieentscheidung auf Basis der St.-Gallen-Konsensusempfehlungen, Adjuvant! online und MammaPrint ${ }^{\circledR}$ mittels eines Markov-Modells und anhand der 70-Gen-Signatur von 305 Tumorproben [24]. Insgesamt waren alle 3 Strategien grundsätzlich vergleichbar, wobei die Therapieentscheidung auf Basis der St.-Gallen-Kriterien die kostenintensivste darstellte. Die gesamten Gesundheitskosten lagen bei $28045 €$ für MammaPrint ${ }^{\circledR}$, $35475 €$ für die St.-Gallen-Kriterien und $26915 €$ für Adjuvant! online. Mittels der 70-Gen-Signatur wurden jedoch die höchsten QALYs erreicht (12,44 vs. 12,20 mit Adjuvant! online und 11,24 mit den St.Gallen-Kriterien). Für MammaPrint ${ }^{\circledR}$ lagen die Kosten pro QALY im Vergleich zu Adjuvant! online bei $4614 €$ pro QALY. Im Vergleich zu den St.-Gallen-Kriterien wurden mittels MammaPrint ${ }^{\circledR}$ mehr QALYs als auch weniger Kosten erzielt. Somit war die 70-Gensignatur im vorliegenden Modell die kosteneffektivste Strategie. Weitere gesundheitsökonomische Modelle sind zur Bewertung der Kosteneffektivität von Berechnungsprogrammen im Vergleich zu molekularen Tests erforderlich - insbesondere mit Integration von PREDICT und PREDICT Plus.

\section{Testverfahren aus Sicht der Patientinnen} $\nabla$

Bei allen genannten mammakarzinomassoziierten Testverfahren zur Therapieentscheidung stellt sich jedoch auch die Frage, ob Patientinnen diese überhaupt wünschen. Genetische Untersuchungen gewinnen mehr und mehr an Bedeutung für die gemeinsame Entscheidungsfindung. In einer Studie wurden 278 Karzinompatientinnen (19\% Mammakarzinom) aus kurativer $(n=153)$ und palliativer Situation $(n=125)$ zum Einsatz von pharmakogenetischen Tests befragt [13]. In der Adjuvanz wünschten 99\% der Befragten einen Test zur Identifikation des Benefits einer Chemotherapie. Im Median würden die Patientinnen und Patienten hier 2000 \$ selbst bezahlen (Range 025000 \$) und eine Wartezeit von 21 Tagen akzeptieren. In der Palliation wünschten $98 \%$ der Befragten einen Test, welcher schwerwiegende Toxizitäten individuell voraussagen könnte. Die Patientinnen und Patienten würden $1000 \$(0-15000 \$)$ selbst finanzieren und 
Clearly patients need to be better informed. They require sufficient basic information to allow them to make a decision for or against a specific test [28]. The benefits and disadvantages of the respective tests must be described and weighed up together with the patient. The existing recommendations in the S3 Guidelines should be presented [15]. For this it would be necessary that attending physicians look at the data on tests and consider the uses of these tests. The assessment of tests from a health economic standpoint offers an additional criterion for their evaluation and makes it easier to assess the respective benefits compared to other prognostic methods.

In addition, it is not reasonable to expect that patients will continue to pay for tests for individualised treatment in future, particularly if it can be clearly shown that these tests optimise treatment and help funding agencies reduce the costs born by the community. Funding agencies must accept individual therapy decisions. It would be useful if funding agencies would support further research and more detailed studies on this topic.

\section{Conclusion}

\section{$\nabla$}

Genetic and molecular tests are initially associated with higher costs. In the longer term, however, costs can be reduced by using these new tests to avoid unnecessary treatment, to improve the effectiveness of systemic therapies by identifying those patients who will benefit, and to optimise the management of side-effects. The reduction in costs achieved with these new tests will affect health economics and ultimately have an impact on health policies. But funding agencies have yet to realise the benefits of these new methods and provide sufficient funding of these test methods.

\section{Conflict of Interest}

None.

\section{References}

1 Albain KS, Barlow WE, Shak S et al.; Breast Cancer Intergroup of North America. Prognostic and predictive value of the 21-gene recurrence score assay in postmenopausal women with node-positive, oestrogen-receptor-positive breast cancer on chemotherapy: a retrospective analysis of a randomised trial. Lancet Oncol 2010; 11: 55-65

2 Anderson K, Jacobson JS, Heitjan DF et al. Cost-effectiveness of preventive strategies for women with a BRCA1 or a BRCA2 mutation. Ann Intern Med 2006; 144: 397-406

3 Beckmann MW, Bader W, Bechtold I et al. Finanzierung und finanzielle Probleme von Leistungen und Strukturen im Fachgebiet Gynäkologie und Geburtshilfe im Jahr 2011 - allgemeine Aspekte und geburtshilfliche Versorgung. II. Artikel der Finanzierungskommission der DGGG e.V. - Teil I. Geburtsh Frauenheilk 2011; 71: 497-510

4 Beckmann MW, Bader W, Bechtold I et al. Finanzierung und finanzielle Probleme von Leistungen und Strukturen im Fachgebiet Gynäkologie und Geburtshilfe im Jahr 2011 - DRG-System und stationäre Versorgung inklusive Urogynäkologie und benigner wie auch maligner gynäkologischer Operationen. II. Artikel der Finanzierungskommission der DGGG e.V. - Teil II. Geburtsh Frauenheilk 2011; 71: 367-380

5 Blohmer JU, Rezai M, Kümmel S et al. Using the 21-gene assay to guide adjuvant chemotherapy decision - making in early-stage breast cancer: a cost-efectiveness evaluation in the German setting. J Med Econ 2013; 16: 30-40

6 Bundesministerium für Bildung und Forschung. Bevölkerung in Deutschland nach Alter und Geschlecht (Tabelle 0.14). 2012. www. datenportal.bmbf.de; last access: April 2013 eine Wartezeit von 14 Tagen akzeptieren. Somit sind die Akzeptanz und der Wunsch solcher Analysen sehr hoch, wobei 20\% der adjuvant und 22\% der palliativ Befragten angaben, noch Verständnisprobleme mit der Bedeutung pharmakogenetischer Tests zu haben.

Es wird deutlich, dass mehr Aufklärungsarbeit geboten ist. Patientinnen benötigen eine adäquate Informationsgrundlage, um Entscheidungen für oder gegen ein Testverfahren treffen zu können [28]. Vorund Nachteile der jeweiligen Tests müssen präsentiert werden und zusammen mit der Patientin abgewogen werden. Zudem sollten die bestehenden Empfehlungen der S3-Leitlinie dargestellt werden [15]. Dazu ist es erforderlich, dass sich die betreuenden Ärztinnen und Ärzte sowohl mit der Datenlage der Testverfahren als auch deren Einsatzmöglichkeiten beschäftigen. Gesundheitsökonomische Evaluationen dieser Tests ermöglichen eine zusätzliche Bewertung und erleichtern die Abschätzung des jeweiligen Benefits im Vergleich der Verfahren.

Des Weiteren ist der Einsatz von Testverfahren für die individualisierte Therapie zukünftig nicht als Selbstzahlerleistung zumutbar, insbesondere, wenn die Therapie nachweislich optimiert wird und die Kostenträger langfristig dadurch Kosten für die Solidargemeinschaft einsparen. Kostenträger müssen sich der individuellen Therapieentscheidung öffnen. Zudem wäre eine Unterstützung von Versorgungsforschungsstudien zu dieser Thematik durch die Kostenträger sinnvoll.

\section{Fazit}

\section{$\nabla$}

Genetische bzw. molekulare Tests sind zunächst mit höheren Kosten verbunden. Langfristig kann jedoch eine Kostenreduktion durch die Vermeidung unnötiger Therapien, die höhere Effektivität von Systemtherapien durch die Identifikation der Patientinnen, die wirklich profitieren, und durch die Optimierung des Nebenwirkungsmanagements erreicht werden. Diese Kostenersparnis kann durchaus gesundheitsökonomisch und somit gesundheitspolitisch relevant sein. Das Verständnis hierfür muss jedoch bei den Kostenträgern noch erwachen, sodass eine adäquate Finanzierung dieser Testsysteme folgt.

\section{Interessenkonflikt}

$\nabla$

Nein.

7 Carey LA, Perou CM, Livasy CA et al. Race, breast cancer subtypes, and survival in the Carolina Breast Cancer Study. JAMA 2006; 295: 24922502

8 Deenen MJ, Cats A, Sechterberger MK et al. Safety, pharmacokinetics (PK), and cost-effectiveness of upfront genotyping of DPYD in fluoropyrimidine therapy. J Clin Oncol 2011; 29 (Suppl.): Abstr. 3606

9 Eiermann W, Rezai M, Kümmel S et al. The 21-gene recurrence score assay impacts adjuvant therapy recommendations for ER-positive, nodenegative and node-positive early breast cancer resulting in a riskadapted change in chemotherapy use. Ann Oncol 2013; 24: 618-624

10 Elkin EB. The cost of cancer care: how much do we spend and how can we spend it better? SABCS 2011

11 Eisemann N, Waldmann A, Katalinic A. Epidemiology of breast cancercurrent figures and trends. Geburtsh Frauenheilk 2013; 73: 130-135

12 Hall PS, McCabe C, Stein RC et al. Economic evaluation of genomic testdirected chemotherapy for early-stage lymph node-positive breast cancer. J Natl Cancer Inst 2012; 104: 56-66

13 Hon H, Qiu X, Tobros K et al. Cancer patient acceptance, understanding, and willingness to pay for pharmacogenetic testing (PGT). J Clin Oncol 2012; 30 (Suppl.): Abstr. 6005 
14 Jacobs VR, Augustin D, Wischnik A et al. Analysis of test-therapy concordance for biomarkers UPA and PAI-1 in primary breast cancer in clinical hospital routine: results of a prospective multi-center study at certified breast cancers in Germany. Cancer Res 2012; 72 (24 Suppl.): $455 \mathrm{~s}-456 \mathrm{~s}$

15 Kreienberg R, Albert U-S, Follmann $M$ et al. Leitlinienprogramm Onkologie der AWMF, Deutschen Krebsgesellschaft e.V. und Deutschen Krebshilfe e.V. Interdisziplinäre S3-Leitlinie für die Diagnostik, Therapie und Nachsorge des Mammakarzinoms. Langversion 3.0. Aktualisierung 2012: 105

16 Lee JA, Shaheen M, Walke T et al. Clinical and health economic outcomes of alternative HER2 test strategies for guiding adjuvant trastuzumab therapy. Expert Rev Pharmacoecon Outcomes Res 2011; 11: 325-341

17 Loi S, Sotiriou C, Haibe-Kains B et al. Gene expression profiling identifies activated growth factor signaling in poor prognosis (Luminal-B) estrogen receptor positive breast cancer. BMC Med Genomics 2009; 2: 37

18 Lüftner D, Lux MP, Maass $N$ et al. Advances in breast cancer - looking back over the year. Geburtsh Frauenheilk 2012; 72: 1117-1129

19 Lux MP, Fasching PA, Löhberg CR et al. Health services research and health economy - quality care training in gynaecology, with focus on gynaecological oncology. Geburtsh Frauenheilk 2012; 71: 1046-1055

20 Lux MP, Reichelt C, Wallwiener D et al. Results of the Zometa cost-utility model for the German healthcare system based on the results of the ABCSG-12 study. Onkologie 2010; 33: 360-368

21 Paik S, Shak S, Tang G et al. A multigene assay to predict recurrence of tamoxifen-treated, node-negative breast cancer. N Engl J Med 2004; 351: 2817-2826

22 Ravdin PM, Siminoff LA, Davis GJ et al. Computer program to assist in making decisions about adjuvant therapy for women with early breast cancer. J Clin Oncol 2001; 19: 980-991

23 Reed SD, Dinan MA, Schulman KA et al. Cost-effectiveness of the 21gene recurrence score assay in the setting of multifactorial decision making for chemotherapy in early-stage breast cancer. J Clin Oncol 2012; 30 (Suppl.): Abstr. 1525
24 Retèl VP, Joore MA, Knauer M et al. Cost-effectiveness of the 70-gene signature versus St. Gallen guidelines and Adjuvant Online for early breast cancer. Eur J Cancer 2010; 46: 1382-1391

25 Robert Koch-Institut; Gesellschaft der epidemiologischen Krebsregister in Deutschland e.V., Hrsg. Krebs in Deutschland 2007/2008. 8. Ausgabe. Berlin: 2012

26 Scharl A, Thomssen C, Harbeck N; on behalf of the AGO Breast Committee. AGO recommendations for diagnosis and treatment of patients with early and metastastic breast cancer: Update 2012. BreastCare 2012; 7: 322-335

27 Sørlie T, Perou CM, Tibshirani R et al. Gene expression patterns of breast carcinomas distinguish tumor subclasses with clinical implications. Proc Natl Acad Sci U S A 2001; 98: 10869-10874

28 Thiel FC, Schrauder MG, Fasching PA et al. Shared decision-making in breast cancer: discrepancy between the treatment efficacy required by patients and by physicians. Breast Cancer Res Treat 2012; 135: 811-820

29 Wishart GC, Azzato EM, Greenberg DC et al. PREDICT: a new UK prognostic model that predicts survival following surgery for invasive breast cancer. Breast Cancer Res 2010; 12: R1

30 Wishart GC, Bajdik CD, Azzato EM et al. A population-based validation of the prognostic model PREDICT for early breast cancer. Eur J Surg Oncol 2011; 37: 411-417

31 Wishart GC, Bajdik CD, Dicks E et al. PREDICT Plus: development and validation of a prognostic model for early breast cancer that includes HER2. Br J Cancer 2012; 107: 800-807

32 Yang M, Rajan S, Issa AM. Cost effectiveness of gene expression profiling for early stage breast cancer: a decision-analytic model. Cancer 2012; 118: 5163-5170

33 Schmidt M, Fasching PA, Beckmann MW et al. Biomarkers in breast cancer - an update. Geburtsh Frauenheilk 2012; 72: 819-832

Deutschsprachige Zusatzinformationen online abrufbar unter: www.thieme-connect.de/ejournals/toc/gebfra. 